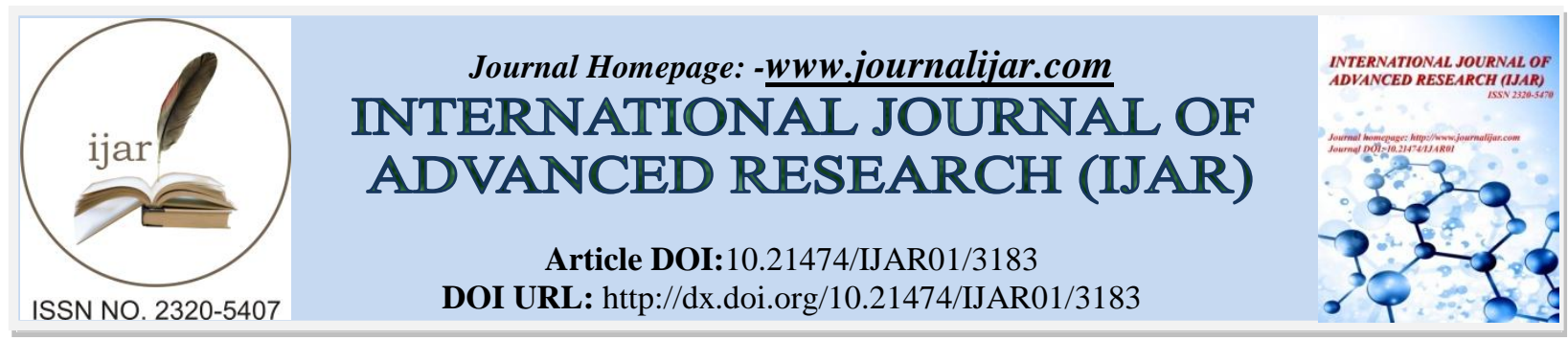

RESEARCH ARTICLE

\title{
ASSESSMENT OF ORAL HYGIENE HABITS AND KNOWLEDGE OF CARIES AMONG UNIVERSITY STUDENTS IN TAIF CITY.
}

\section{Mohamed Wael Bassuoni ${ }^{1}$, Hesham Mohamed Elsharkawy ${ }^{2}$, Abdulrahman Hani Sabbagh ${ }^{3}$ and Mutaz Fahad Felemban ${ }^{3}$.}

1. Associate Professor of Community and Preventive Dentistry, Faculty of Dentistry, Taif University, Kingdom of Saudi Arabia.

2. Associate Professor of Oral Medicine and Periodontology, Faculty of Dentistry, Taif University, Kingdom of Saudi Arabia.

3. Faculty of Dentistry, Taif University, Taif, Kingdom of Saudi Arabia.

\section{Manuscript Info}

Manuscript History

Received: 18 December 2016

Final Accepted: 10 January 2017

Published: February 2017

Key words:-

Oral hygiene habits, oral hygiene behaviors , knowledge of caries , tooth brushing, caries .

\section{Abstract}

Background: Obtaining a baseline information of the oral hygiene habits and knowledge of caries is essential and it will help in establishment of adequate preventive programs and proper allocation of available dental services. Therefore, the aim of the present study was to examine self-reported oral hygiene habits and caries knowledge of Saudi students in Taif University.

Methods: A cross-sectional study was conducted in Taif University. A self-reported, anonymous and structured questionnaire was distributed to a random sample of 600 students $(n=600$; Male $(M)=300$, Female $(F)=300)$ from different colleges. The questionnaire included two sections, one section for assessing the oral hygiene behavior (Q1-Q11) and another to assess the knowledge of caries (Q12-Q20). The students were requested to remain in the classroom after the lecture to answer the questions. The participation was voluntary and the answers were anonymous. The data was collected and then analyzed using Statistical Package for Social Sciences (SPSS, v.21) software to calculate the frequency distribution and percentage.

Results: The male and female responses are presented in tables to show the distribution frequency of each question. In addition, the overall percentages of total students' responses are presented in figures. Results of the first part of the questionnaire show that $47.5 \%$ (41.21\% of males, $53.94 \%$ of females) practice good oral hygiene behavior. Conversely, $52.5 \%$ of students $(58.79 \%$ of males and $46.06 \%$ of females) practice incorrect behavior. The results of the second part show that $45.04 \%$ of the students $(47.11 \%$ of males, $42.96 \%$ of females) have correct knowledge about caries. In contrast, $54.96 \%$ of students $(52.89 \%$ of males, $57.04 \%$ of females) lack that knowledge about caries.

\section{Conclusion:}

The findings of this study indicate that more than half of the students practice incorrect oral hygiene behaviors and lack the basic knowledge about caries and its related information, so this direct us to the importance of conducting oral health promotion programs to raise the 
awareness and motivate students to practice the ideal and correct oral hygiene behavior for the prevention from oral diseases.

Copy Right, IJAR, 2017,. All rights reserved.

\section{Introduction:-}

Oral health is an important component of general health and overall quality of life ${ }^{[1]}$. The two most common oral diseases; caries and periodontal disease, continue to be highly prevalent in most regions of the world ${ }^{[2]}$. Behavior plays a major role in the prevention of both diseases in adequate oral hygiene habits and compliance with regular preventive dental visits essential for their control ${ }^{[3]}$. Self-preventive measures for the removal of bacterial dental plaque through adequate use of the toothbrush and dental floss have been demonstrated to reduce the prevalence of caries $^{[4,5]}$ and periodontal diseases ${ }^{[6,7]}$. Similarly, compliance with regular preventive dental examination and prophylaxis visits have been documented as essential for the prevention and early diagnosis of oral diseases ${ }^{[8-9]}$. Self-preventive oral health behavior and oral hygiene habits are influenced by several factors including patient motivation, attitude, and value system ${ }^{[10-11]}$. Consequently, differences in oral hygiene habits have been shown to be related to culture and geographic region ${ }^{[12-13]}$. For instance, while $73-83 \%$ of school children in Norway, Germany, Sweden, Denmark, and Austria brushed their teeth twice daily [ ${ }^{12}$ ], such tooth brushing frequency was reported by only $19-46 \%$ of patients in Lithuania, Saudi Arabia (Riyadh), and Japan ${ }^{[13-14]}$.

Until today, limited information is available on the oral hygiene habits of Saudi adults, so obtaining a baseline information of the oral hygiene habits and knowledge of caries is essential and it will help in establishment of adequate preventive programs and proper allocation of available dental services. Therefore, the aim of this study was to examine self-reported oral hygiene habits and caries knowledge of Saudi students in Taif University.

\section{Materials and Methods:-}

A cross sectional study was conducted in Taif University. A self-reported, anonymous and structured questionnaire was distributed to a random sample of 600 students (300 males and 300 females) from different colleges. The students were requested to remain in the classroom after the lecture to answer the questions. The participation was voluntary and the answers were anonymous. The study protocol was approved by the review committee of the Faculty of Dentistry in Taif University. The questionnaire used in this study covered two aspects as follow:

The first part of the questionnaire (Q1-Q11) covered oral hygiene behavior: (Tooth brushing frequency, time spent for bushing, replacement of toothbrush, cleaning of tongue ,use of dental floss, use of mouthwash, purpose of visiting dentist, frequency of eating candies, frequency of having soft drinks, frequency of smoking, use of sugar with tea and coffee ).

The second part (Q12 - Q20) covered oral health knowledge : ( Role of sugar bacteria, saliva, soft drinks and fresh juices in getting decay, role of fluoride in toothpastes, importance of preserving the teeth from extraction , ability of teeth to regenerate, role of milk bottles to develop decay in children).

The data were collected and then analyzed using Statistical Package for Social Sciences (SPSS, v.21) software to calculate the frequency distribution and percentage.

\section{Results:-}

The questionnaire included two sections, one section for assessing the oral hygiene behavior and another to assess the knowledge of caries. The self-reported oral hygiene behavior of male and female are presented in table (1). In addition, the overall percentages of total students' responses are presented in figure (1):

Q1: $53.3 \%$ of males $(n=160)$ and $15 \%$ of females $(n=45)$ brush their teeth once a day , 28.7\% of males (n=86) and $60 \%$ of females (180) brush their teeth twice a day, $10 \%$ of males $(n=32)$ and $23.3 \%$ of females $(n=70)$ brush more than two times a day and $7.3 \%$ of males $(n=22)$ and $1.7 \%$ of females $(n=5)$ never brush their teeth .

Q2: $43.3 \%$ of males $(n=130)$ and $23.3 \%$ of females $(n=70)$ spend only around 30 seconds for brushing, $51.3 \%$ of males $(n=154)$ and $65 \%$ of females $(n=195)$ spend $2-3$ minutes for bushing, $5.3 \%$ of males $(n=16)$ and $11.7 \%$ of females $(n=35)$ spend more than 3 minutes for brushing their teeth. 
Q3:20\% of males $(n=60)$ and $21.7 \%$ of females $(n=65)$ replace their tooth brush every month , $43.3 \%$ of males $(n=130)$ and $60 \%$ of females replace their toothbrush every $3-4$ months , $17.3 \%$ of males $(n=52)$ and $15 \%$ of females $(n=45)$ replace their toothbrush every 6-8 months and $19.3 \%$ of males $(n=58)$ and $3.3 \%$ of females replace their toothbrush every year or never replace it .

Q4: $57.7 \%$ of males $(n=170)$ and $58.3 \%$ of females $(n=175)$ clean their tongue every day, 13.3\% of males ( $n=40)$ and $23.3 \%$ of females $(n=70)$ clean it once a week , $7.3 \%$ of males $(n=22)$ and $0 \%$ of female $(n=0)$ clean it once a month and $23 \%$ of males $(n=68)$ and $18 \%$ of females $(n=55)$ don't clean it .

Q5: $10 \%$ of males $(n=30)$ and $25 \%$ of females $(n=75)$ use the dental floss once a day, $6 \%$ of males $(n=18)$ and $6.7 \%$ of females use it twice a day, $4 \%$ of males $(n=12)$ and $1.7 \%$ of females $(n=5)$ use it more than two times a day and $80 \%$ of males $(n=240)$ and $66.7 \%$ of females $(n=200)$ don't use the dental floss .

Q6: $16.7 \%$ of males $(n=50)$ and $41.7 \%$ of females $(n=125)$ use the mouthwash once a day, $11.3 \%$ of males $(n=34)$ and $11.7 \%$ of females $(n=35)$ use it , $2 \%$ of males $(n=6))$ and $0 \%$ of female $(n=0)$ use it more than two times a day and $70 \%$ of males $(n=210)$ and $46.7 \%$ of females $(n=140)$ don't use it.

Q7 : 50\% of males $(n=150)$ and $41.7 \%$ of females $(n=125)$ visits the dentist when severe pain presents , $25.3 \%$ of males $(n=76)$ and $41.7 \%$ of females $(n=125)$ visit the dentist when the pain start, $8.7 \%$ of males $(n=26)$ and $8.3 \%$ of females $(n=25)$ visit the dentist for periodic examination and $16 \%$ of males $(n=48)$ and $8.3 \%$ of females $(n=25)$ don't visit the dentist at all .

Q8: $36.7 \%$ of males $(n=110)$ and $53.3 \%$ of females $(n=160)$ have candies and biscuits multiple times during the day , $33.3 \%$ of males $(n=100)$ and $31.7 \%$ of females $(n=95)$ have candies and biscuits once a day, $15.3 \%$ of males $(n=46)$ and $6.7 \%$ of females $(n=20)$ have candies and biscuits once a week and $14.7 \%$ of males $(n=44)$ and $8.3 \%$ of females $(n=25)$ rarely have biscuits and candies .

Q9: $36.7 \%$ of males $(n=110)$ and $26.7 \%$ of females $(n=80)$ have soft drinks multiple times during the day , $28.7 \%$ of males $(n=86)$ and $26.7 \%$ of females $(n=80)$ have soft drinks once a day , $23.3 \%$ of males $(n=70)$ and $26.7 \%(n=80)$ have soft drinks once a week and $11.3 \%$ of males $(n=34)$ and $20 \%$ of females $(n=60)$ rarely have soft drinks .

Q10: $18 \%$ of males $(n=54)$ and $3.3 \%$ of females $(n=10)$ smoke multiple times during the day, 1.3\% of males $(n=4)$ and $3.3 \%$ of females $(n=10)$ smoke once a day, $0.67 \%$ of males $(n=2)$ and $0 \%$ of female $(n=0)$ and $80 \%$ of males $(\mathrm{n}=240)$ and $93.3 \%$ of females $(\mathrm{n}=280)$ rarely or never smoke.

Q11: $24.7 \%$ of males $(n=74)$ and $35 \%$ of females $(n=105)$ use one spoon with tea or coffee , 50\% of males $(n=150)$ and $40 \%$ of females $(n=12)$ use two spoons of sugar with tea or coffee , $20 \%$ of males $(n=60)$ and $15 \%$ of females $(n=45)$ use three spoons or more with tea or coffee and $5.3 \%$ of males $(n=16)$ and $10 \%$ of females $(n=30)$ don't use sugar with tea or coffee.

The second section of the questionnaire assessed the knowledge about caries among males and females as presented in table (2). In addition, the overall percentages of total students' responses are presented in figure (2):

Q12: $65.3 \%$ of males $(n=196)$ and $86.7 \%$ of females $(n=260)$ consider sugar as the main factor for decay, $15.3 \%$ of males $(n=46)$ and $5 \%$ of females $(n=15)$ think the opposite and $19.3 \%$ of males $(n=58)$ and $8.3 \%$ of females $(n=25)$ don't know if sugar is responsible or not.

Q13: $20 \%$ of males $(n=60)$ and $31.7 \%$ of females $(n=95)$ think that fluoride is added to toothpastes to give it a good taste, $40 \%$ of males $(n=120)$ and $33.3 \%$ of females $(n=100)$ know that fluoride isn't added for enhancing taste and $40 \%$ of males $(n=120)$ and $35 \%$ of females $(n=105)$ don't know what is the purpose of adding fluoride.

Q14: $86.7 \%$ of males $(n=260)$ and $88.3 \%$ of females $(n=265)$ know that bacteria has a role in developing decay and $5.3 \%$ of males $(n=16)$ and $3.3 \%$ of females $(n=10)$ think that bacteria has no role in developing decay and $8 \%$ of males $(n=24)$ and $8.3 \%$ of females $(n=25)$ don't know if bacteria is involved in the process or not. 
Q15: $59.3 \%$ of males $(n=178)$ and $41.7 \%$ of females $(n=125)$ know that saliva has a protecting action against decay, $17.3 \%$ of males $(n=52)$ and $13.3 \%$ of females $(n=40)$ think that saliva has no role against decay and $23.3 \%$ of males $(\mathrm{n}=70)$ and $45 \%$ of females $(\mathrm{n}=135)$ don't know if saliva has a protecting action or not.

Q16: $20 \%$ of males $(n=60)$ and $41.7 \%$ of females $(n=125)$ think that extraction of the tooth is the best wat to treat it, $64 \%$ of males $(n=192)$ and $45 \%$ of females $(n=135)$ know that isn't right and $16 \%$ of males $(n=48)$ and $13.3 \%$ of females $(n=40)$ don't know if extraction is the best solution or not.

Q17: $32 \%$ of males $(n=96)$ and $53.3 \%$ of females $(n=160)$ think that teeth can regenerate again if care is taken, $46.7 \%$ of males $(n=140)$ and $30 \%$ of females $(n=90)$ know that's not true and $21.3 \%$ of males $(n=64)$ and $16.7 \%$ of females $(n=50)$ don't know if teeth has the ability to regenerate or not.

Q18: $46.7 \%$ of males $(n=140)$ and $68.3 \%$ of females $(n=205)$ think that soft drinks cause decay because they contain gases, $25.3 \%$ of males $(n=76)$ and $16.7 \%$ of females $(n=50)$ know that's not right and $28 \%$ of males $(n=84)$ and $15 \%$ of females $(n=45)$ don't know if soft drink is causing decay because of gases or not.

Q19:22.7\% of males $(n=68)$ and $33.3 \%$ of females $(n=100)$ know that children are at risk of developing decay from milk bottles, $43.3 \%$ of males $(n=130)$ and $36.7 \%$ of females $(n=110)$ think not and $34 \%$ of males $(n=102)$ and $30 \%$ of females $(n=90)$ don't know if milk bottles increasing the risk or not.

Q20: $14 \%$ of males $(n=42)$ and $11.7 \%$ of females $(n=35)$ know that fresh juices can harm our teeth, $67.3 \%$ of males $(n=202)$ and $71.7 \%$ of females think that fresh juices will not harm our teeth and $18.7 \%$ of males $(n=56)$ and $16.7 \%$ of females $(n=50)$ don't know if fresh juices will harm our teeth or not.

Table 1:- Frequency distribution and percentage of students' responses regarding oral hygiene behavior

\begin{tabular}{|c|c|c|c|c|c|c|}
\hline & & $\mathbf{A}$ & B & $\mathbf{C}$ & D & Total \\
\hline \multirow{5}{*}{$\begin{array}{l}\text { 1- Times of tooth } \\
\text { brushing a day }\end{array}$} & & Once a day & Twice & $>2$ & None & \\
\hline & \multirow[b]{2}{*}{ M } & 160 & 86 & 32 & 22 & 300 \\
\hline & & $53.33 \%$ & $28.67 \%$ & $10.67 \%$ & $7.33 \%$ & $100 \%$ \\
\hline & \multirow[t]{2}{*}{$\mathrm{F}$} & 45 & 180 & 70 & 5 & 300 \\
\hline & & $15.00 \%$ & $60.00 \%$ & $23.33 \%$ & $1.67 \%$ & $100 \%$ \\
\hline \multirow{5}{*}{$\begin{array}{l}\text { 2-Time spent for } \\
\text { cleaning teeth }\end{array}$} & & 30 seconds & $2-3 \mathrm{~min}$ & $>3 \min$ & & \\
\hline & \multirow[t]{2}{*}{$\mathrm{M}$} & 130 & 154 & 16 & & 300 \\
\hline & & $43.33 \%$ & $51.33 \%$ & $5.33 \%$ & & $100 \%$ \\
\hline & \multirow[t]{2}{*}{$\mathrm{F}$} & 70 & 195 & 35 & & 300 \\
\hline & & $23.33 \%$ & $65.00 \%$ & $11.67 \%$ & & $100 \%$ \\
\hline \multirow{5}{*}{$\begin{array}{l}\text { 3-When do you } \\
\text { replace your } \\
\text { toothbrush }\end{array}$} & & Every month & $\begin{array}{l}\text { Every } 3-4 \\
\text { months }\end{array}$ & $\begin{array}{l}\text { Every } 6-8 \\
\text { months }\end{array}$ & $\begin{array}{l}\text { Every year } \\
\text { / never }\end{array}$ & \\
\hline & \multirow[t]{2}{*}{$\mathrm{M}$} & 60 & 130 & 52 & 58 & 300 \\
\hline & & $20.00 \%$ & $43.33 \%$ & $17.33 \%$ & $19.33 \%$ & $100 \%$ \\
\hline & \multirow[t]{2}{*}{$\mathrm{F}$} & 65 & 180 & 45 & 10 & 300 \\
\hline & & $21.67 \%$ & $60.00 \%$ & $15.00 \%$ & $3.33 \%$ & $100 \%$ \\
\hline \multirow[t]{5}{*}{$\begin{array}{l}\text { 4- Do you clean } \\
\text { your tongue? }\end{array}$} & & Yes ,Every day & $\begin{array}{l}\text { Yes, Once a } \\
\text { week }\end{array}$ & $\begin{array}{l}\text { Yes,Once a } \\
\text { month }\end{array}$ & No & \\
\hline & \multirow[t]{2}{*}{$\mathrm{M}$} & 170 & 40 & 22 & 68 & 300 \\
\hline & & $56.67 \%$ & $13.33 \%$ & $7.33 \%$ & $22.67 \%$ & $100 \%$ \\
\hline & \multirow[t]{2}{*}{$\mathrm{F}$} & 175 & 70 & 0 & 55 & 300 \\
\hline & & $58.33 \%$ & $23.33 \%$ & $\mathbf{0 . 0 0 \%}$ & $18.33 \%$ & $100 \%$ \\
\hline \multirow[t]{5}{*}{$\begin{array}{l}\text { 5-Do you use dental } \\
\text { floss }\end{array}$} & & Yes, once a day & $\begin{array}{l}\text { Yes,twice a } \\
\text { day }\end{array}$ & $\begin{array}{l}\text { Yes, more than } \\
2 \text { times a day }\end{array}$ & No & \\
\hline & \multirow[t]{2}{*}{$\mathrm{M}$} & 30 & 18 & 12 & 240 & 300 \\
\hline & & $10.00 \%$ & $6.00 \%$ & $4.00 \%$ & $80.00 \%$ & $100 \%$ \\
\hline & \multirow[t]{2}{*}{$\mathrm{F}$} & 75 & 20 & 5 & 200 & 300 \\
\hline & & $25.00 \%$ & $6.67 \%$ & $1.67 \%$ & $66.67 \%$ & $100 \%$ \\
\hline 6-Do you use a & & Yes, once a day & Yes, twice a & Yes, more than & No & \\
\hline
\end{tabular}




\begin{tabular}{|c|c|c|c|c|c|c|}
\hline \multirow[t]{5}{*}{ mouthwash } & & & day & 2 times a day & & \\
\hline & \multirow[t]{2}{*}{$\mathrm{M}$} & 50 & 34 & 6 & 210 & 300 \\
\hline & & $16.67 \%$ & $11.33 \%$ & $2.00 \%$ & $70.00 \%$ & $100 \%$ \\
\hline & \multirow[t]{2}{*}{$\mathrm{F}$} & 125 & 35 & & 140 & 300 \\
\hline & & $41.67 \%$ & $11.67 \%$ & $0.00 \%$ & $46.67 \%$ & $100 \%$ \\
\hline \multirow[t]{5}{*}{$\begin{array}{l}\text { 7- When do you visit } \\
\text { the dentist? }\end{array}$} & & $\begin{array}{lll}\begin{array}{l}\text { When } \\
\text { presents }\end{array} & \text { sever } & \text { pain } \\
\end{array}$ & $\begin{array}{l}\text { When the } \\
\text { pain starts }\end{array}$ & $\begin{array}{l}\text { For periodic } \\
\text { examination }\end{array}$ & Never & \\
\hline & \multirow[t]{2}{*}{$\mathrm{M}$} & 150 & 76 & 26 & 48 & 300 \\
\hline & & $50.00 \%$ & $25.33 \%$ & $8.67 \%$ & $16.00 \%$ & $100 \%$ \\
\hline & \multirow[t]{2}{*}{$\mathrm{F}$} & 125 & 125 & 25 & 25 & 300 \\
\hline & & $41.67 \%$ & $41.67 \%$ & $8.33 \%$ & $8.33 \%$ & $100 \%$ \\
\hline \multirow{5}{*}{$\begin{array}{l}\text { 8-How many times } \\
\text { do you eat candies } \\
\text { and biscuits? }\end{array}$} & & $\begin{array}{l}\text { Multiple times during a } \\
\text { day }\end{array}$ & Once a day & Once a week & Rarely & \\
\hline & \multirow[t]{2}{*}{$\mathrm{M}$} & 110 & 100 & 46 & 44 & 300 \\
\hline & & $36.67 \%$ & $33.33 \%$ & $15.33 \%$ & $14.67 \%$ & $100 \%$ \\
\hline & \multirow[t]{2}{*}{$\mathrm{F}$} & 160 & 95 & 20 & 25 & 300 \\
\hline & & $53.33 \%$ & $31.67 \%$ & $6.67 \%$ & $8.33 \%$ & $100 \%$ \\
\hline \multirow{5}{*}{$\begin{array}{c}\text { 9-How many times } \\
\text { do you have soft } \\
\text { drinks? }\end{array}$} & & $\begin{array}{l}\text { Multiple times during a } \\
\text { day }\end{array}$ & Once a day & Once a week & Rarely & \\
\hline & \multirow[t]{2}{*}{$\mathrm{M}$} & 110 & 86 & 70 & 34 & 300 \\
\hline & & $36.67 \%$ & $28.67 \%$ & $23.33 \%$ & $11.33 \%$ & $100 \%$ \\
\hline & \multirow[t]{2}{*}{$\mathrm{F}$} & 80 & 80 & 80 & 60 & 300 \\
\hline & & $26.67 \%$ & $26.67 \%$ & $26.67 \%$ & $20.00 \%$ & $100 \%$ \\
\hline \multirow[t]{6}{*}{$\begin{array}{l}\text { 10-How many times } \\
\text { do you smoke? }\end{array}$} & & $\begin{array}{l}\text { Multiple times during a } \\
\text { da }\end{array}$ & Once a day & Once a week & $\begin{array}{l}\text { Rarely / } \\
\text { Never }\end{array}$ & \\
\hline & & $\mathrm{y}$ & & & & \\
\hline & \multirow[t]{2}{*}{ M } & 54 & 4 & 2 & 240 & 300 \\
\hline & & $18.00 \%$ & $1.33 \%$ & $0.67 \%$ & $80.00 \%$ & $100 \%$ \\
\hline & \multirow[t]{2}{*}{$\mathrm{F}$} & 10 & 10 & 0 & 280 & 300 \\
\hline & & $3.33 \%$ & $3.33 \%$ & $0.00 \%$ & $93.33 \%$ & $100 \%$ \\
\hline \multirow{5}{*}{$\begin{array}{c}\text { 11-Number of sugar } \\
\text { spoons with tea / } \\
\text { coffee }\end{array}$} & & One spoon & Two spoons & $\begin{array}{l}\text { Three } \\
\text { more }\end{array}$ & Non & \\
\hline & \multirow[t]{2}{*}{$\mathrm{M}$} & 74 & 150 & 60 & 16 & 300 \\
\hline & & $24.67 \%$ & $50.00 \%$ & $20.00 \%$ & $5.33 \%$ & $100 \%$ \\
\hline & \multirow[t]{2}{*}{$\mathrm{F}$} & 105 & 120 & 45 & 30 & 300 \\
\hline & & $35.00 \%$ & $40.00 \%$ & $15.00 \%$ & $10.00 \%$ & $100 \%$ \\
\hline
\end{tabular}

$\mathrm{M}=$ Male $\& \mathrm{~F}=$ Female . 


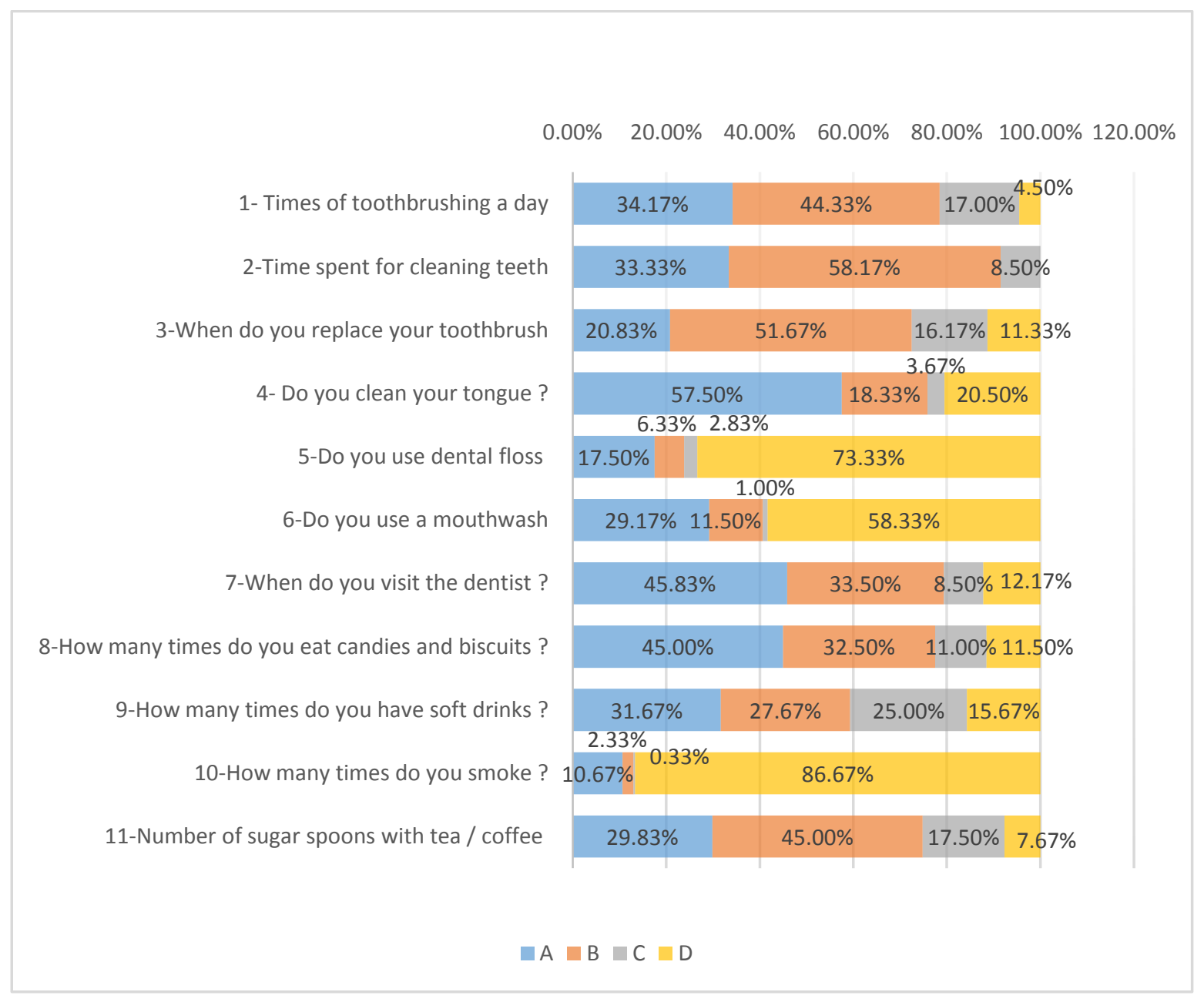

Figure 1:- Percentage of total students' responses regarding oral hygiene behavior (refer to table 1 for A,B ,C and D for each question) :

Table 2:- Frequency distribution and percentage of students' responses regarding knowledge about caries

\begin{tabular}{|c|c|c|c|c|c|}
\hline \multirow{5}{*}{$\begin{array}{l}\text { 12- Sugar is considered as the main } \\
\text { factor for decay }\end{array}$} & & Yes & No & I don't know & \\
\hline & \multirow[t]{2}{*}{$\mathrm{M}$} & 196 & 46 & 58 & 300 \\
\hline & & $65.33 \%$ & $15.33 \%$ & $19.33 \%$ & $100 \%$ \\
\hline & \multirow[t]{2}{*}{$\bar{F}$} & 260 & 15 & 25 & 300 \\
\hline & & $86.67 \%$ & $5.00 \%$ & $8.33 \%$ & $100 \%$ \\
\hline \multirow{5}{*}{$\begin{array}{l}\text { 13-Fluraide is added to the } \\
\text { toothpaste for giving it a good taste }\end{array}$} & & Yes & No & I don't know & \\
\hline & \multirow[t]{2}{*}{$\mathrm{M}$} & 60 & 120 & 120 & 300 \\
\hline & & $20.00 \%$ & $40.00 \%$ & $40.00 \%$ & $100 \%$ \\
\hline & \multirow[t]{2}{*}{$\mathrm{F}$} & 95 & 100 & 105 & 300 \\
\hline & & $31.67 \%$ & $33.33 \%$ & $35.00 \%$ & $100 \%$ \\
\hline \multirow[t]{5}{*}{ 14-Bacteria has a role in decay } & & Yes & No & I don't know & \\
\hline & \multirow[t]{2}{*}{$\mathrm{M}$} & 260 & 16 & 24 & 300 \\
\hline & & $86.67 \%$ & $5.33 \%$ & $8.00 \%$ & $100 \%$ \\
\hline & \multirow[t]{2}{*}{$\mathrm{F}$} & 265 & 10 & 25 & 300 \\
\hline & & $\mathbf{8 8 . 3 3 \%}$ & $3.33 \%$ & $8.33 \%$ & $100 \%$ \\
\hline \multirow{3}{*}{$\begin{array}{l}\text { 15- Saliva protect the teeth from } \\
\text { getting decayed : }\end{array}$} & & Yes & No & I don't know & \\
\hline & \multirow[t]{2}{*}{$\mathrm{M}$} & 178 & 52 & 70 & 300 \\
\hline & & $59.33 \%$ & $17.33 \%$ & $23.33 \%$ & $100 \%$ \\
\hline
\end{tabular}




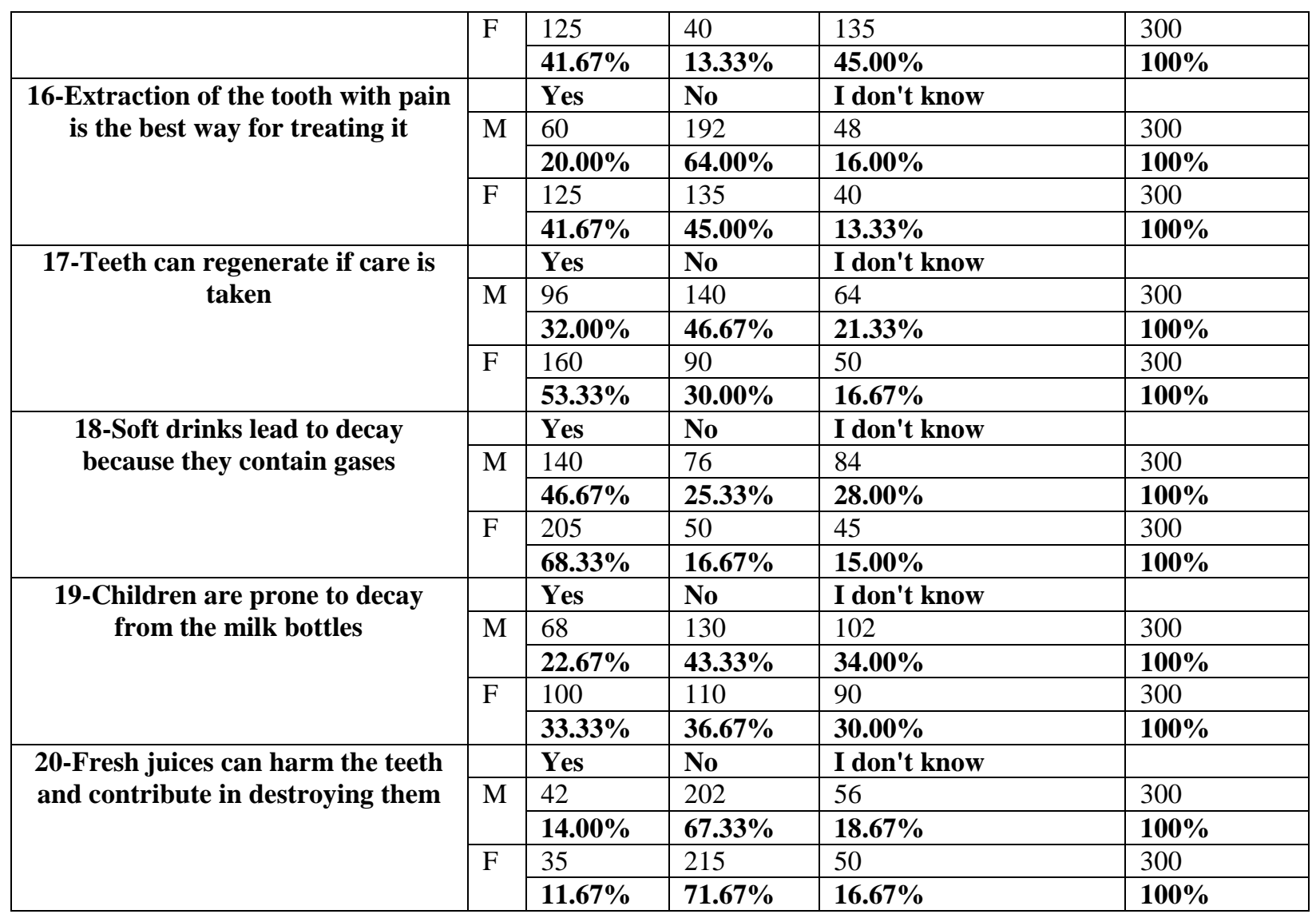

\section{$0.00 \%$}

12- Sugar is considered as the main factor for decay

13-Fluraide is added to the toothpaste for giving it a good taste

14-Bacteria has a role in decay

15- Saliva protect the teeth from getting decayed:

16-Extraction of the tooth with pain is the best way for treating it

17-Teeth can regenerate if care is taken

18-Soft drinks lead to decay because they contain gases

19-Children are prone to decay from the milk bottles

20-Fresh juices can harm the teeth and contribute in destroying them

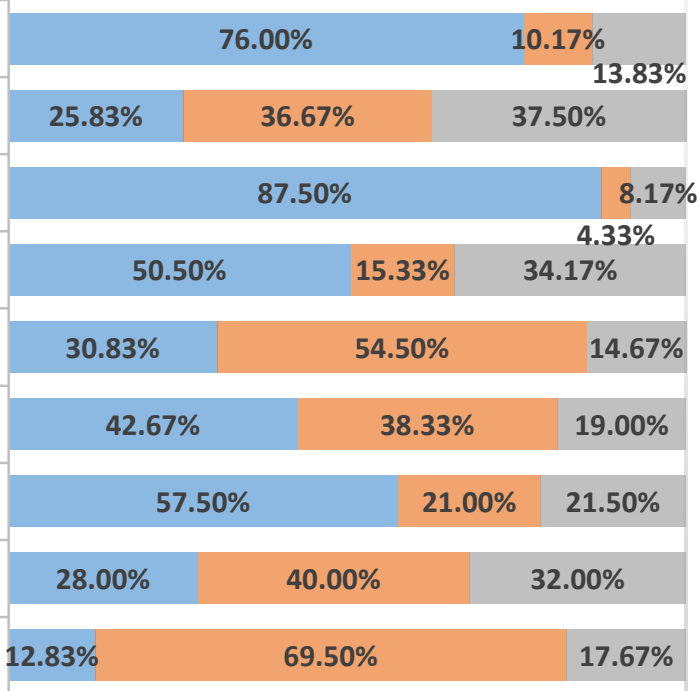

Yes No I don't know

Figure 2:- Percentage of total students' responses regarding knowledge about caries 
The data in figure 3 shows the percentage of good behavior and incorrect behavior among Taif university students. The good behavior included : (brushing twice or more daily, spending $2-3$ minutes while cleaning the teeth , replacing the toothbrush every 3-4 months, cleaning the tongue once or more daily ,using dental floss once or more daily, using mouthwash, visiting the dentist for periodic examination, reduced frequency of eating candies and biscuits and drinking soft drinks, non-smoking, using not more than one spoon of sugar with tea or coffee ).

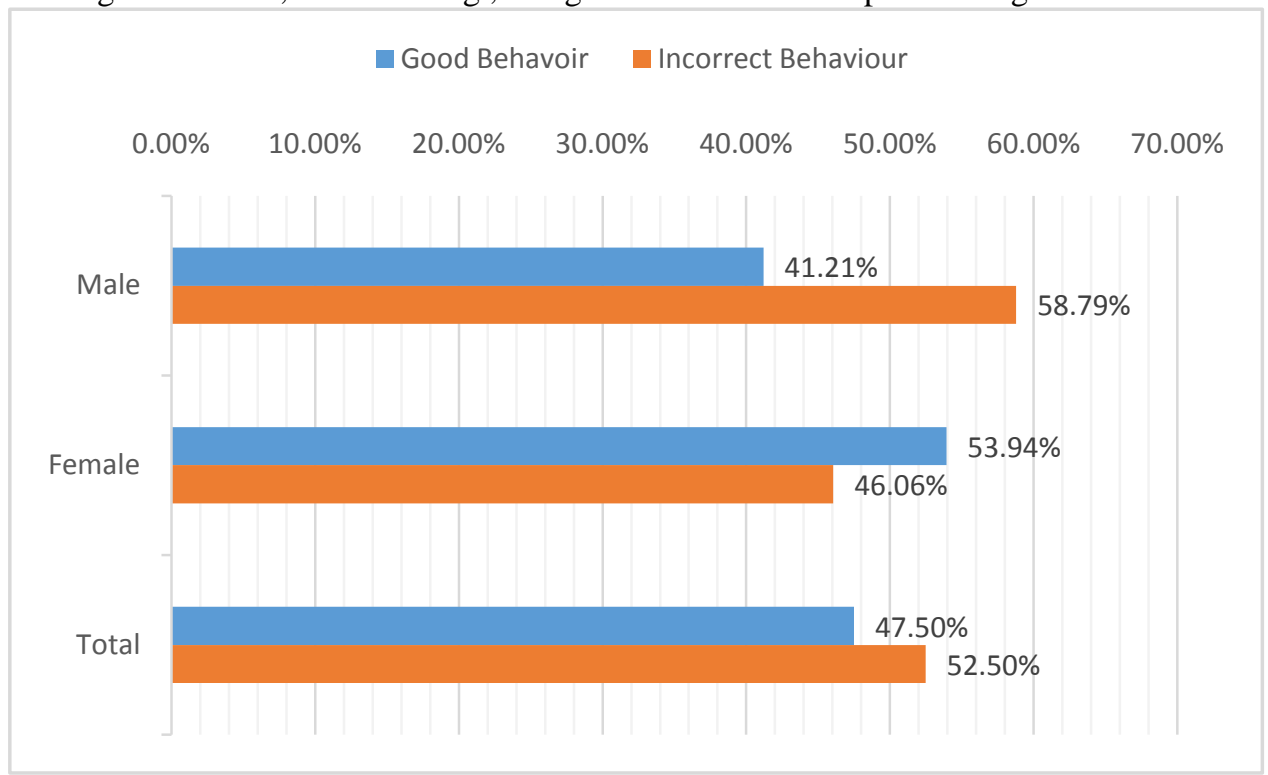

Figure 3:- The oral hygiene behavior among Taif university students

The data in figure 4 shows the percentage of Taif University students who have the correct knowledge about caries compared with people who lack that knowledge. The knowledge assessed include: ( The role of sugar and bacteria in developing caries, the protective role of saliva and fluoride, the importance of preserving teeth from extraction , ability of teeth to regenerate, role of milk bottles to develop decay in children )

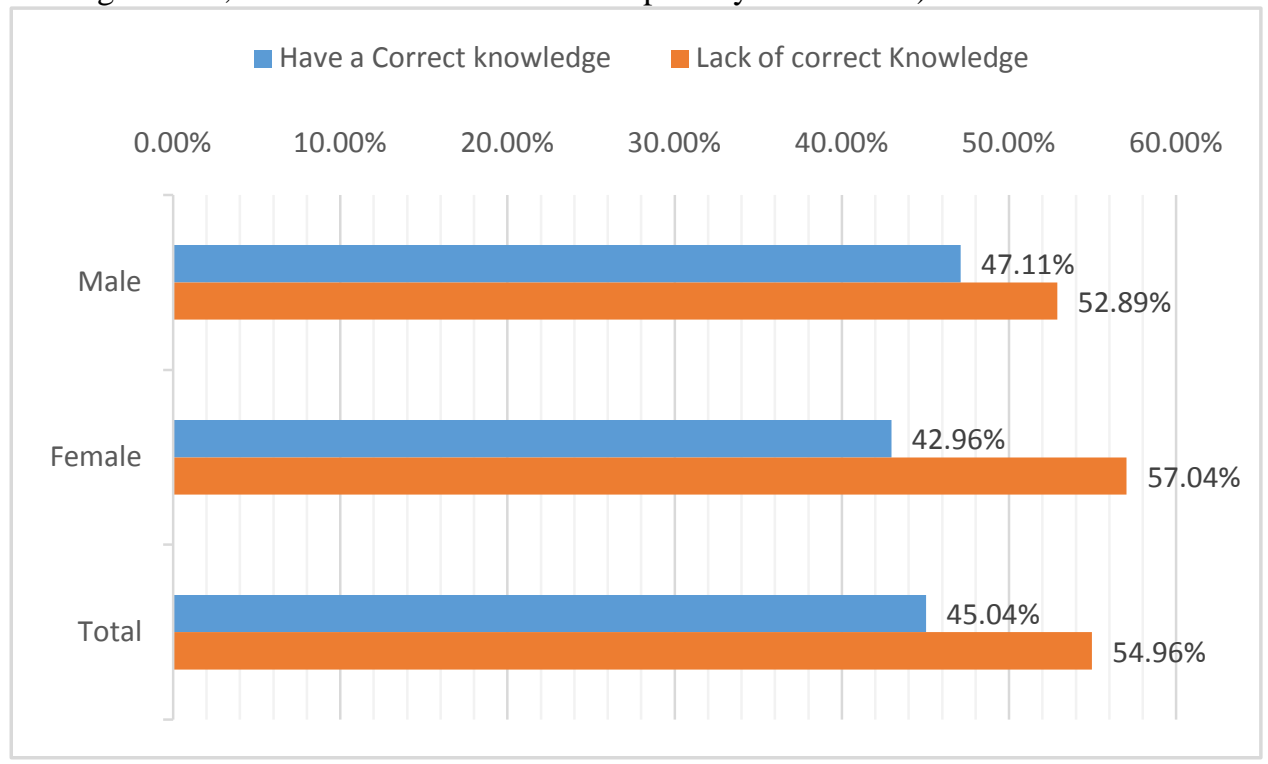

Figure 4:- The knowledge about caries among Taif university students

\section{Discussion:-}

This research presents; to the best of our knowledge, new data as no researcher has investigated the oral hygiene behavior or the knowledge of caries among students in Taif University or even among population in Taif. The first part of the questionnaire revealed a huge negligence on the using of mouthwashes and dental floss as $73.33 \%$ of the 
sampled student (the males more than the females) don't include the use of dental floss in their oral hygiene routine, but it's still better compared to a study reported $89 \%$ who don't use the dental floss in Denmark ${ }^{[15]}$ and $83.2 \%$ in Iran [16]. Also about $58.33 \%$ of the sampled student (the males are more than the females) don't use a mouthwash. Regarding tooth brushing about $44.33 \%$ of the sampled students follow the international guidelines that indicate brushing at least twice a day, and our result is in the range of other studies which reported such tooth brushing frequency by $19-46 \%$ of patients in Lithuania, Saudi Arabia(Riyadh), and Japan ${ }^{[13-14]}$. It's also noticed that women had higher odds of brushing teeth twice a day than men and that is parallel with other findings ${ }^{[17-18]} ; 34.17 \%$ brush their teeth once a day and $17 \%$ brush more than two times a day. A minor percent (approximately 9\%) of sampled students do not use the toothbrush on a daily basis and we should consider them without hesitation. The behavior of visiting the dentist for periodic examination is minimum as most of the samples students (more than half) only visit the dentist when sever pain presents or when the pain starts, this finding is similar to another literatures which found that about $60 \%$ of the subjects paid no attention to signs of caries if there was no pain ${ }^{\text {[19] }}$. The consumption of candies and biscuits is more in female) than in males (about half of females consume them multiple times during the day). However, the males drink soft drinks and soda more than the females (about one third of males). In total, this study indicates high consumption of sugar which disagrees with results of Zhu et al ${ }^{[19]}$. Our findings also show that smoking in males is more than in females obviously with only about one fifth of males practicing this unhealthy habit. The use of extra sugar with tea or coffee is unhealthy and it is considered as a factor for developing caries and other health problems; however, more than the half of sampled students use extra sugar which also contrast the results of Zhu et $a l^{[19]}$ and that should be taken into consideration. Lastly, figure 3 shows that more than half of the samples students practice incorrect oral hygiene methods (with the females practice less incorrect behavior than males). This noticed good oral hygiene behavior among women has been reported in various studies ${ }^{[15,20,21]}$.This may be because women have flexible daily routine ${ }^{[22]}$ which is suggested to promote higher teeth cleaning behavior. Also, women are more motivated to follow oral hygiene behavior that might be due to the esthetic value which they care about.

The second part of the questionnaire revealed that majority of sample students know that sugar and bacteria are responsible for caries which is a positive aspect. Although half of the sample student think that saliva has no role in protection against decay or do not know if it has a role or not. Also the majority of sampled students think fluoride is added for taste or do not know if it is for taste or not. There is also lack of knowledge about the cause soft drink causing decay, the harmful effect of fresh juices on the teeth and the importance preservation of teeth in the majority of sampled students (more than half). Also, majority of sampled students (about two thirds) think that teeth can regenerate or do not know if it can or not. Finally, figure 2 shows that more than the half of sampled students lack the correct knowledge (females lack knowledge more than males) which does not coincide with a research that suggest females were having relatively more oral health-related knowledge ${ }^{[23]}$.

The results of the present study emphasize the need of oral health promotion programs to be conducted to increase the awareness and motivate the people to practice the correct and last current oral hygiene behavior by explaining the importance of preserving the teeth and illustrating the oral diseases that could develop if the recommendations are not followed.

\section{Limitation of the study:-}

This study is giving baseline information about oral hygiene behavior and knowledge among males and females but it does not take into consideration the effect of other variables such as the socio-demographic factor and the economic status of each subject. Another limitation is that this study just gives information regarding University students only and that necessitate the need for conducting more comprehensive study including large population samples.

\section{Conclusion:-}

The findings of the present study indicate that more than the half of students practice incorrect oral hygiene behaviors and they lack basic knowledge about caries and its related information, hence, this directs us to the importance of conducting oral health promotion programs to raise the awareness and motivate students to practice the ideal and correct oral hygiene behavior for the prevention from oral diseases. 


\section{References:-}

1. Petersen PE, Kwan S: Evaluation of community-based oral health promotion and oral disease prevention WHO recommendations for improved evidence in public health practice. Community Dent Health 2004; 21(suppl):319-329.

2. Petersen PE: Challenges to improvement of oral health in the 21 st century - the approach of the WHO Global Oral Health Programme. Int Dent J 2004; 54(suppl 1):329-343.

3. Honkala E: Oral health promotion with children and adolescents; in Schou L, Blinkhorn A (eds): Oral Health Promotion. New York, Oxford University Press, 1993, pp 169-187.

4. Ainamo J, Parviainen K: Occurrence of plaque, gingivitis and caries as related to selfreported frequency of toothbrushing in fluoride areas in Finland. Community Dent Oral Epidemiol 1979; 7: 142-146.

5. Tinanoff N: Dental caries risk assessment and prevention. Dent Clin North Am 1995; 39: 709-719.

6. Hill HC, Levi PA, Glickman I: The effects of waxed and unwaxed dental floss on interdental plaque accumulation and interdental gingival health. J Periodontol 1973; 44: 411-413.

7. Lang NP, Cumming BR, Loe H: Toothbrushing frequency as it relates to plaque development and gingival health. J Periodontol 1973; 44: 396-405.

8. Axelsson $\mathrm{P}$, Lindhe $\mathrm{J}$ : The significance of maintenance care in the treatment of periodontal disease. $\mathrm{J}$ ClinPeriodontol 1981; 8: 281-294.

9. Ramfjord SP: Maintenance care for treated periodontitis patients. J ClinPeriodontol 1987; 14: $433-437$.

10. Adair PM, Pine CM, Burnside G, Nicoll AD, Gillett A, Anwar S: Familial and cultural perceptions and beliefs of oral hygiene and dietary practices among ethnically and socio-economically diverse groups. Community Dent Health 2004; 21(suppl):102-111.

11. Davidson PL, Rams TE, Andersen RM: Socio-behavioral determinants of oral hygiene practices among USA ethnic and age groups. Adv Dent Res 1997; 11: 245-253.

12. Kuusela S, Honkala E, Kannas L, Tynjala J, Wold B: Oral hygiene habits of 11-year-old schoolchildren in 22 European countries and Canada in 1993/1994. J Dent Res 1997; 76: 1602-1609.

13. Petersen PE, Aleksejuniene J, Christensen LB, Eriksen HM, Kalo I: Oral health behavior and attitudes of adults in Lithuania. ActaOdontolScand 2000; 58: 243-248.

14. Almas K, Al-Malik TM, Al-Shehri MA, Skaug N: The knowledge and practices of oral hygiene methods and attendance pattern among school teachers in Riyadh, Saudi Arabia. Saudi Med J 2003; 24: 1087-1091.

15. Christensen LB, Petersen PE, Krustrup U, Kjøller M. Self-reported oral hygiene practices among adults in Denmark. Community Dent Health. 2003;20(4):229-35.

16. Asgari F, Majidi A, Koohpayehzadeh J, Etemad K, Rafei A. Oral hygiene status in a general population of Iran, 2011: a key lifestyle marker in relation to common risk factors of non-communicable diseases. International Journal of Health Policy and Management. 2015;4(6):343-352. doi:10.15171/ijhpm.2015.18.

17. Olusile AO, Adeniyi AA, Orebanjo O. Self-rated oral health status, oral health service utilization, and oral hygiene practices among adult Nigerians. BMC Oral Health. 2014;14(1):140. doi: 10.1186/1472-6831-14-140

18. Al-Shammari KF, Al-Ansari JM, Al-Khabbaz AK, Dashti A, Honkala EJ. Self-reported oral hygiene habits and oral health problems of Kuwaiti adults. Med PrincPract. 2007;16(1):15-21. doi: 10.1159/000096134

19. Zhu L, Petersen PE, Wang HY, Bian JY, Zhang BX .Oral health knowledge, attitudes and behaviour of adults in China. Int Dent J 2005; 55: 231-241

20. Jensen O, Gabre P, Sköld UM, Birkhed D. Is the use of fluoride toothpaste optimal? Knowledge, attitudes and behaviour concerning fluoride toothpaste and toothbrushing in different age groups in Sweden. Community Dent Oral Epidemiol. 2012;40(2):175-84. doi: 10.1111/j.1600-0528.2011.00658.x.

21. Tseveenjav B, Suominen AL, Hausen H, Vehkalahti MM. The role of sugar, xylitol, toothbrushing frequency, and use of fluoride toothpaste in maintenance of adults' dental health: findings from the Finnish National Health 2000 Survey. Eur J Oral Sci. 2011;119(1):40-7. doi: 10.1111/j.1600-0722.2010.00804.x.

22. Abegg C, Croucher R, Marcenes WS, Sheiham A. How do routines of daily activities and flexibility of daily activities affect tooth-cleaning behavior? J Public Health Dent. 2000;60(3):154-8. doi: 10.1111/j.17527325.2000.tb03321.x

23. Hongal S, Torwane NA, Goel P, Byarakele C, Mishra P, Jain S. Oral health-related knowledge, attitude and practices among eunuchs (hijras) residing in Bhopal City, Madhya Pradesh, India: A cross-sectional questionnaire survey. Journal of Indian Society of Periodontology. 2014;18(5):624-631. doi:10.4103/0972$124 X .142459$. 